\title{
A Case for Public Sector Ethics
}

\author{
Colin Hicks
}

If some do not take ethics seriously, it is an indictment of them, not ethics; like conscience, the more it is demeaned, the more it protrudes.

\section{Bowman, 1996}

In June 2007, as part of the achievement of its development goals, the State Services Commission (SSC) published a revised code of conduct (SSC, 2007a) to apply to most state service employees. The code is about 'standards of integrity and conduct' - essentially, to be fair, impartial, responsible and trustworthy. The initiatives of the SSC in recent times are to be commended, but do they go far enough?

In the context of contemporary New Zealand state sector management and administration, words like integrity and values, or responsibility, are more likely to be used than the term ethics. Almost no reference to normative or prescriptive ethics, or professional ethics, is made in official publications. The language of ethics is all but ignored.

An apparent absence of ethical and moral theory to inform and enrich public management is puzzling in the light of a growing public sector ethics literature, and a coincidental 'confidence gap' with respect to the attitude of citizens towards public institutions. In other developed countries with similar forms of government there has been considerably more emphasis on ethics education and training and on integrating ethics into public management than is evident in New Zealand.

Governmental organisations in New Zealand ought to review their collective approach and reassess the place of public sector ethics in the scheme of public administration. Indeed, they ought to adopt a rich definition of public sector ethics to take account of how state organisations relate to their stakeholders, and how state organisations account for the public interest in their objects and missions. A rich definition might well encompass how organisations are managed, too. In making this plea I am not implying there was a time in the past in government service here when it was any different, or that ethical and moral theory of whatever persuasion was more evident than now.

My intent here is not to promote a particular moral theory or interpretation of public sector ethics. Rather, I firmly believe that ethical theory can help officials in their practical activity, and administrative tasks. I take the view that theory provides us with a framework to make reasoned, informed and systematic judgments and critical decision making. Knowledge and understanding (of ethical theory) are important in that process. Being ethical in government service is not an end in itself merely a means to the end of promoting and enhancing public trust and confidence, and efficient and effective government administration.

In layman's terms, ethics is about how we ought to behave, or doing the right thing. For public officials that means how to behave in a particular role, and how to live up to the expectations of others - colleagues, employers, politicians, citizens, users of public services, and so forth. To discern what constitutes an ethical decision or action requires a degree of reasoning to make choices not just between right and wrong, or good or bad, or just and unjust, but between right and most right, or ethical and most ethical. The exercise of discretion in these matters cannot be determined just by reference to a code of conduct or accompanying guidance material, as important as those minimum standards may be in the scheme of things. The reasoning processes and instincts are informed by experience and knowledge acquired through the practice of public management and the internalisation of fundamental public sector values applying to all agencies of the state. The reasoning processes are also informed by a good knowledge and 
understanding of ethical theory and practice as it applies to public office and the administrative sphere of government.

Establishing boundaries of good conduct is important in any institution, but a definition of ethics in the context of government should not leave any doubt that it means more than avoiding the use of public office for personal gain or benefit. The meaning should lean more in the direction of actively promoting public benefit - towards a very high standard of justice (goods promoted) rather than towards a modest but more manageable standard of integrity (harms avoided) (Uhr, 2005, p.39).

An onus to demonstrate a substantial public good goes to the heart of understanding public sector ethics. A substantial public good is best achieved through the maintenance of well-articulated and explicit ethical standards that go beyond the expected minima. These standards need to be understood in the light of the nature of public service obligation and those fundamental values or common beliefs that may define professional ethics in that context. The pertinent values have been distilled as honour (the highest standards of responsibility, integrity and principle), justice (fairness and regard for the rights of others, especially respect for the dignity and worth of individuals) and benevolence (the other-regarding essence of public service - a disposition to do good and to promote the welfare of others) (Denhardt, 1990). Those same values applying to individual behaviour need to also apply to the way organisations in the state sector behave. Recent publicity given to electricity supply authorities illustrates how important it is for these organisations to express public good values in all they do. That means 'going the extra mile', and doing what ought to be done rather than what can be done, consistent with ethical values and standards.

Not doing harm is not the same as doing good. Being ethical is not achieved only by following the rule of law, or, indeed, a code of conduct. An absence of unethical conduct is not a sufficient test of whether a state sector agency is fully ethical or not. Too often, when the topic of ethics is discussed it is in the context of breaches of conventions or proscriptive codes, or even illegal conduct, and therefore focuses on where these minimum boundaries should be drawn. In my view this is not the best starting point to understand public sector ethics. It seems preferable to accentuate the positive, affirm whose interests ought to be promoted and enhanced, and stimulate discussion of how public servants can raise their ethical performance well above the expected minimum standards.

The first written code of conduct was issued by the State Services Commission in 1989, under Don Hunn's stewardship. He recognised the need to codify and reiterate what he believed to be the constants governing behaviour of public officials in a reformed state sector. Hunn stated publicly his view that there was a need to go beyond the code and to provide guidance in respect of the 'administrative behaviour' of public servants (Martin, 1991, p1). A few years later a comprehensive guidance series was published to provide, in a consolidated and accessible form, reference to appropriate standards and values to guide the responsible official in all aspects of his or her work (SSC, 1995). In short, the papers amounted to a reference resource of public sector ethics standards and values. (These papers survive in the archive section of the SSC's website.)

In November 2000, in response to a growing public (and political) disquiet, the minister of state services established the State Sector Standards Board (SSSB) to be assured of an ethical, public-serving state sector and to provide the basis for government to set out its expectations of the state sector in a clear and concise statement of values. Two years later the SSSB, having produced a variety of reports on the broad issue of state sector standards in the interim, said,

There do not appear to have been any significant developments in the ethos of the State Sector since the Board's last report. Concerns about the ethical and managerial standards of organisations in the State Sector preceded the establishment of this Board and, in the words of the State Services Commissioner, 'cast a shadow' over public organisations. Regrettably, instances of inappropriate behaviour continue to come to light and underline our observation in last year's report that there is 'a need to be vigilant, in terms of behavioural standards, effective systems, and commitment by leadership'. (SSSB, 2002)

In 2005 the State Services Commission published a set of six broad 'aspirations' or goals to be achieved over a five-year period to contribute to an overall goal of developing 'a system of world class professional state 
services serving the government of the day and the needs of New Zealanders' (SSC, 2005). One of the goals is to 'strengthen trust in the state services and reinforce the spirit of service'. Progress towards achievement of the goals was monitored most recently in May 2007. A key finding is that only a small majority of adult New Zealanders express trust in public services (Colmar Brunton, 2007, p.3). Putting aside any scepticism about the accuracy of such surveys, it appears that the State Services Commission will have to do much more for significant improvement than planned to date.

The SSC initiatives in recent times have all been aimed at: improving services; meeting citizen's expectations; and building trust. The key drivers of satisfaction with, and trust in, state services have been identified, and benchmarks set. A revised code of conduct to apply to most of the state services has been issued (SSC, 2007a), and guidance material published (SSC, 2007b). In all this effort only two references to ethics have been made: with respect to possible conflicts with professional ethics (legal, accounting, etc.), and with reference to the work of ethics committees (such as research, and bio-ethics). This may not be significant of itself, but this omission suggests that these days a profession of statecraft (Martin, 1988) is not explicitly recognised. Or, it could mean a debate is still to be had about the nature of government and the 'good society', and the nature and purpose of public service.

It is not peculiar to New Zealand that we have experienced a heightened perception of dubious or unethical conduct in public life this century. When things go wrong the facts and fallacies tend to be exposed more readily and for longer periods than in the past. Appearance of wrongdoing is as damaging to reputation and image as any substantiated transgression. These phenomena reinforce a propensity for public officials to be extremely risk averse - to create more rules (of what not to do), and more codes (of minimal standards). Inevitably, the result is more compliance with tighter accountability mechanisms, and perhaps a preoccupation with toeing the line, which diverts attention from the practice of statecraft.

An obsession with accountability will most certainly affect professional pride and integrity, and may even be counter-productive. The same may be said of rulesetting, particularly if the standards are set and assessed internally, leaving those on the 'outside' no real basis on which to judge for themselves the merits or otherwise of a particular case. The on-going story involving the Ministry for the Environment may be one in point. The principal actors in the affair - the minister, the chief executive and the state services commissioner - seemed at pains to act on the basis of appearance, or their conduct was somehow moderated by public relations considerations. That is, they seemed determined to provide only so much information to assuage news media and political appetites for a good story, or to gain political advantage. In this case, public officials should have been more publicly forthcoming, indeed more ethical and more accountable. If terms like openness, transparency and truth are to have real meaning they need to be expressed to the full, so that others may judge the actions of those in positions of public trust and responsibility. (In this case, a person was appointed to a senior communications position in the Ministry for the Environment, but was soon required to leave the job after the chief executive learned of the appointee's personal relationship with an employee in the office of the leader of the opposition. It was said by the state services commissioner that the offer of employment was withdrawn because the appointee had an unmanageable conflict of interest. Later, it was revealed that the minister for the environment had expressed some concerns over the appointment. Although the case may have involved an apparent or real conflict of interest on the part of the appointee, the prime minister accepted her minister's resignation when it became evident that he had not been wholly truthful in his public explanations with respect to his involvement in the controversy. At the time of writing, the State Services Commission is about to carry out an investigation into the affair.)

It can be expected (it may even be a healthy sign) that citizens are naturally hesitant to trust governments. Uhr (2005) suggests there is probably no good reason why citizens should take on trust what public sector organisations say about their integrity, or how accountable they are, when the standards are set within the state sector and self-regulated in the main. It is possible that the standards are not high enough or do not reflect the reasonable expectations of citizens; or that there are not common definitions of such phrases as conflicts of interest, or words like accountability, and responsibility.

For example, I believe accountability means more than mere reporting. Accountability in the context 
of government is the obligation to demonstrate continued official trustworthiness through justification of performance in a position of responsibility. In an ethical sense it also means explaining, and if necessary providing answers for, official actions or decisions (or inactions and indecisions, too). Such justification needs to reflect the fundamental ethical values of public service. It is ironic that the case referred to above followed hard on the heels of the promulgation of a state sector code of conduct promoting the values of fairness, impartiality, responsibility and trustworthiness. We are all left to wonder what motivated the withdrawal of the appointee's offer of employment, and whether we can trust those in positions of responsibility to do the right thing.

While it is true that most of us think about ethics in the context of individual behaviour, there is value in considering ethical standards for organisations, too. How organisations behave and give expression to their values, and to their nature and purpose, will undoubtedly affect the conduct of employees and the image of the organisation. Many state sector agencies have developed high-level statements of purpose and values, and these should ideally permeate and direct everything that is done in the name of the entity. For instance, there should be a consistency in the way the organisation operates its 'customer service' standards and its employee relations. Performance management systems should recognise and reward high ethical conduct in the same manner as high productivity or efficiency. The drivers should be the fundamental ethical values of public service.

Most of us understand what constitutes personal integrity, and we recognise varying degrees of professional integrity. We may assume that organisational integrity is a reflection of an agency's reputation for delivering on its promises and being true to its stated values and ideals in everything it does. Such a status, however, is not sustained in the absence of good governance and management. A reputation is not usually a product of chance, or piecemeal attention, or even the personal conduct of individual employees. Organisational integrity is not the sum of individual or professional integrity in a particular entity.

In the light of falling public confidence it is time to focus even more attention on the ownership dimension of the businesses of government. The ownership interest forms the bridge between good management practices and public-regarding behaviour and gives substance to the special characteristics of state sector organisations (Hicks and Scanlon, 1998). In this regard an ethics framework is just as important for maintaining and promoting organisational integrity as it is for understanding and managing people in organisations, or processes. When integrity is questioned in state sector organisations the focus of inquiry is more on individual than institutional conduct, and more on the operations than the governance level of responsibility. I believe the focus needs to be widened.

It is not so long ago that the term 'systemic failure' was current. We now understand a lot more about what tragic effects squeezing out apparent inefficiencies can have, and how inappropriate cultures can develop in publicly-owned institutions. Lessons learned from Cave Creek might apply equally well to our understanding and management of organisational integrity to avoid the possibility of what might be termed 'systemic ethical failure'. Whereas one failure has to do with what is done (or not), the other is very much concerned with a crucial element of performance - how things are done. In government the how is as important as the what, even more so.

For the sake of public trust and confidence, and good governance, a fuller and richer understanding of ethics needs to be appreciated. The practice of government and government business is a qualitatively different exercise from the private sector, and the distinction needs to be recognised when considering what constitutes ethical practice (Bishop and Preston, 2000). In my view the contemporary approach looks more like a clip-on, confined largely to a code of minimal conduct. The place of ethics and ethical theory in the scheme of things needs to be integral to good public management and administration, and applied systematically. Ethics may not be a panacea for the apparent 'confidence gap' in state sector services, but it certainly deserves more honest and objective attention than it appears to receive at present.

\section{References}

Bishop, P. and N. Preston (eds) (2000) Local Government: public enterprise and ethics, Leichhardt, NSW: The Federation Press

Bowman, J.S. (1996) 'Public service ethics: prospects, problems, and promise in an age of reform', keynote 
address presented at the 'Public Sector Ethics - between past and future' Ethics in the Public Service 5th international conference, Brisbane, 5-9 August

Colmar Brunton (2007) Satisfaction and Trust in the State Services, report prepared for the State Services Commission, Wellington: Colmar Brunton

Denhardt, K.G. (1990) 'Unearthing the moral foundations of public administration: honour, benevolence, and justice', in J.S. Bowman (ed.), Ethical Frontiers in Public Management, San Francisco: Jossey-Bass

Gregory, R. and C. Hicks (1999) 'Promoting public service integrity: a case for responsible accountability', Australian Journal of Public Administration, 58 (4)

Hicks, C. and G. Scanlon (1998) 'Integrating ethics', in C. Sampford \& N. Preston with C.-A. Bois (eds), Public Sector Ethics: finding and implementing values, Leichhardt, NSW: The Federation Press

Martin, J. (1988) 'Is there a profession of statecraft?', in M. Clark (ed.), Constitutional Changes: intended and unintended, Wellington: SSRFC

Martin, J. (1991) Public Service and the Public Service: administrative practice in a time of change, Wellington: State Services Commission (preface by D.K. Hunn, state services commissioner)

Martin, J. (1994) 'Ethics in public service: the New Zealand experience', in N. Preston (ed.), Ethics for the Public Sector: education and training, Leichhardt, NSW: The Federation Press

State Sector Standards Board (2002) The Ethos of the State Sector, Wellington: State Services Commission

State Services Commission (1995) New Zealand Public Service Principles, Conventions and Practice, Wellington: State Services Commission

State Services Commission (2005) Development Goals for the State Services, Wellington: State Services Commission

State Services Commission (2007a) Integrity and Conduct, Wellington: State Services Commission

State Services Commission (2007b) Understanding the Code: guidance for state servants, Wellington: State Services Commission

Uhr, J. (2005) Terms of Trust: arguments over ethics in Australian government, Sydney: University of NSW Press
Colin Hicks is a former public servant of long standing, who held positions of responsibility in the former Department of Justice, and in the State Services Commission. Until recently he was a course co-ordinator in public sector ethics for the Master of Public Management programme at the School of Government, VUW. His email address is: Colin.Hicks@xtra.co.nz 